\title{
SHIFTS IN LEAF PHENOLOGY OF THREE HIMALAYAN OAK SPECIES: ROLE OF WOOD WATER PROPERTIES
}

\author{
Deepak B. Chand ${ }^{1 *}$, Kanta Poudyal ${ }^{1}$ and P.K. Jha ${ }^{2}$ \\ ${ }^{1}$ Amrit Science Campus, Tribhuvan University, Kathmandu, Nepal \\ ${ }^{2}$ Central Department of Botany, Tribhuvan University, Kathmandu, Nepal \\ *Email: deepuchand2000@yahoo.com
}

\begin{abstract}
An investigation has been done with the three Himalayan oak species at Phulchowki Hill Lalitpur Nepal to relate leaf phenology responses of trees to wood water properties. We recorded the wood water content, wood density, water in wood and leaf phenological patterns of three evergreen oak species (Quercus semecarpifolia, Quercus lamellosa and Quercus glauca) for 2 years. Our results revealed significant changes in leaf phenology within oak species between years, with shifts in leaf emergence, leaf damage and leaf senescence. Shifts in tree leaf phenology found in studied years suggest that the inter-annual and monthly variation in wood water properties could attribute to shift in tree leaf phenology.
\end{abstract}

Key words: Leaf phenology, Wood water content, Wood density, Water in wood, Oak species.

\section{INTRODUCTION}

Understanding in what manner climatic indicators affect the timing of periodic life cycle events in plants (phenology) is a key factor in anticipating the effects of climate change on vegetation. Plant phenology has been proposed as an indicator of climatic difference and global change by the Intergovernmental Panel on Climate Change (IPCC 2007). Climate change may intensely alter water resources through changes in the timing of precipitation in many regions (Christensen et al. 2007, IPCC 2011, Smith 2011). Phenological patterns may be influenced by variations in rainfall (Singh and Kushwaha 2005, Sakai et al. 2006, Ragusa-Netto and Silva 2007); temperature (Chmielewski and Rotzer 2001,
Sparks and Menzel 2002, Matsumoto et al. 2003, Badeck et al. 2004, Moriondo and Bindi 2007, Aitken et al. 2008, Thakur et al. 2008, Nord and Lynch 2009), radiation, photoperiod (Yadav and Yadav 2008) and drought (Borchert et al. 2002, Poudyal et al. 2004, Anderson et al. 2005, Singh and Kushwaha 2005 2006, Yadav and Yadav 2008, Nord and Lynch 2009) or by abundance of pollinators, seed dispersers, seed predators, or herbivores (Curran and Leighton 2000); from which temperature and moisture variables are of principal importance. Shifts in plant phenology, such as the timing of budburst, present some of the most visible evidence of the impacts of climate change in recent decades (Walther et al. 2002, Menzel et al. 2006). Vegetative and flowering 
phenology of trees in dry tropics is primarily affected by the periodicity of rainfall and soil water availability. Water stress is most frequently cited as a primary factor responsible for the timing of phenological events in tropical dry forests (Singh and Kushwaha 2005).

Plants are adapted to the annual seasonal cycle and all the life-cycle stages are regulated by seasonal atmospheric changes. So, it is important to acquaint with cyclical events such as appearance of buds, leaf emergence, leaf development, leaf senescence, flowering and fruiting from year to year, and scrutinize how they relate to the weather patterns. For plants, the seasonal timing of such events can be critical to survival and reproduction. Erratic weather patterns will have long-term effects on life-cycle stages and phenological patterns of almost all plant species (Moza and Bhatnagar 2005). Phenophases, in fact, not only reveal growth behaviour of an individual tree species, but also indicate the magnitude and duration of growth. Leaf phenology being a major determinant of water and $\mathrm{CO}_{2}$ fluxes, recent studies have clearly show that growing season length controls net ecosystem primary productivity and that phenological shifts have already modified the annual carbon cycle of terrestrial ecosystems (Davi et al. 2006). Climate indicators such as variation in temperature and rainfall closely influence phenophases of different tree species (Thakur et al. 2008). It is evident that climate change will occur during the long lifespan of tree species and changes in phenology may be the major visible short-term response (Badeck et al. 2004). In fact, tree phenological observations have proved to be most effective impact indicators of climate change (Kushwaha and Singh 2008).

The Himalayan region is understood to be a hot spot of climate change as the rate of warming in this region are significantly higher than the global average of $0.74^{\circ} \mathrm{C}$ over the past 100 years (IPCC 2007). The DHM (2017) has estimated that the mean temperature in Nepal during 1971-2014 has risen with an average of $0.056^{\circ} \mathrm{C}$ year ${ }^{-1}$ but that increases varied from place to place and precipitation changed over the same time period is more variable and uncertain; a) insignificant positive precipitation trend in the some districts in three seasons (winter, pre-monsoon and monsoon), b) insignificant decrease in monsoon precipitation in majority of districts east of $84 \mathrm{E}$ longitude, and c) insignificant highest decreasing rainfall trend in all seasons in the High Mountains and insignificant positive trend in all seasons, except in postmonsoon, in Terai. In this article, we examine relationship between tree leaf phenology of three Himalayan oak species and wood water properties patterns at Phulchowki Hill, Lalitpur, Nepal.

\section{Materials and Methods}

\section{Study site}

The study area is situated in the Himalayan region (Phulchowki Hill, Lalitpur, Nepal) between $27^{\circ} 23^{\prime} 15.1^{\prime \prime}$ and $27^{\circ} 23^{\prime} 17.5^{\prime \prime} \mathrm{N}$ of latitude and $85^{\circ} 30^{\prime} 31^{\prime \prime}$ and $85^{\circ} 30^{\prime} 38^{\prime \prime} \mathrm{E}$ of longitude, at an elevation ranging between 2421 and 2643 masl. It is a part of sub-Himalayan Mahabharat region with extensive diverse forests mostly dominated by broad-leaved evergreen trees. The natural vegetation of Phulchowki Hill is characterized by three distinct evergreen broad-leaved forests types: mixed Schima- Castanopsis forest, Oak-Laurel forest and evergreen oak forest. The study area has four seasons round the year: cold and dry winter (December to February), pre-monsoon dry summer (March to May), monsoon (June to September) and post monsoon (October-November). Monsoon climate is prevalent in the study area. Meteorological data were collected from the Godavari Station of Department of Hydrology and Meteorology, Kathmandu, Nepal located at a distance of $1 \mathrm{~km}$ from the study site at 1527 masl. Mean annual temperature is $14.8^{\circ} \mathrm{C}$, with a mean 
minimum temperature of the coldest month (January) of $8.2^{\circ} \mathrm{C}$ and a mean maximum temperature of the warmest month (June) of $21.9^{\circ} \mathrm{C}$. The annual rainfall is $1338 \mathrm{~mm}$ on average with about more than $80 \%$ of this occurring between mid-June and mid-September. The monthly rainfall and temperature is illustrated in Fig. 1. There is no perennial source of water above $1600 \mathrm{~m}$ in Phulchowki Hill.

\section{Species characteristics}

Quercus semecarpifolia belongs to Fagacaceae is a large evergreen oak. Leaves are dark glossy green. The leaves of young tress and coppice shoots have sharp spines on the margin but in the older trees margins are smooth. The ripe acorns are dark brown, almost black, globular in shape.

Quercus lamellosa belongs to Fagacaceae is a medium - sized to large evergreen oak. Leaves are spirally arranged. The flowers are catkins, the female flowers maturing into broad acorns $2-3 \mathrm{~cm}$ long and 3-4 $\mathrm{cm}$ broad, set in a deep cupule with concentric rings of woody scales.

Quercus glauca belongs to Fagacaceae is a small to medium-sized evergreen oak. The leaves are a distinct deep purple-crimson on new growth, soon turning glossy green above, glaucous bluegreen below, with a serrated margin. The flowers are catkins, and the fruit are acorns with series of concentric rings on the outside of the acorn cup.

\section{Phenological observations}

Phenological observations were done in sampled trees of all species as well as in nonsampled ones for a general acuity. Three twigs were marked on each sampled tree and phenological events such as leaf emergence, leaf damage, leaf senescence, flowering and fruiting were tabulated for each month of observation. Timing of leaf emergence, leaf damage, leaf senescence, flowering and fruiting were recorded every month at the time of wood sampling.

\section{Wood properties}

Wood samples of three oak species, Quercus semecarpifolai, Quercus lamellosa and Quercus glauca were collected from representative trees of each species at monthly intervals, except for the monsoon months. Wood sample were collected 19 times from October 2015 to June 2017. One monsoon month's observation was made in September 2016. Three individual trees of each species were randomly selected for sample collection. From each tree a single wood sample (diameter $5 \mathrm{~mm}$, length 35 to $55 \mathrm{~mm}$ ) was collected from breast height $(137 \mathrm{~cm})$ using an increment borer. Wood sample was collected during midday (1200 to $1400 \mathrm{~h}$ ). After the bark was removed from the sample, it was packed in an airtight plastic tube and placed in the shade to protect from direct sun light. Wood sample fresh mass was taken to $0.001 \mathrm{~g}$, length and diameter were measured. It was oven dried for $24 \mathrm{~h}$ at $80^{\circ} \mathrm{C}$ to obtain dry mass. Volume of each wood sample was calculated from its measured length and the diameter of the wood sample. Then wood water content, wood density and water in wood were calculated.

\section{Statistical analysis}

Analysis of variance (ANOVA) and least significance difference test (LSD) were done separately for all variables. SPSS 16.0 for Windows (2010) was used for statistical analysis.

\section{RESULTS}

\section{Wood water properties}

Wood water content $\left(\mathrm{W}_{\mathrm{c}}\right)$, density of wood $\left(\mathrm{W}_{\mathrm{D}}\right)$ and water in wood per volume $\left(\mathrm{W}_{\mathrm{w}}\right)$ showed significant variation among the sampled months 
and years $\left(\mathrm{W}_{\mathrm{c}}, \mathrm{W}_{\mathrm{D}}, \mathrm{W}_{\mathrm{w}}-\mathrm{P}<0.001\right) . \mathrm{W}_{\mathrm{c}}$ showed insignificant variation with sampled species $(\mathrm{P}=0.34) . \mathrm{W}_{\mathrm{D}}$ and $\mathrm{W}_{\mathrm{w}}$ showed significant variation among the sampled species $\left(\mathrm{W}_{\mathrm{D}} \mathrm{P}=0.005\right.$ and $\mathrm{W}_{\mathrm{w}}$ $\mathrm{P}=0.002$ ) (Table 1). Mean values of $\mathrm{W}_{\mathrm{c}}$ and $\mathrm{W}_{\mathrm{D}}$ were higher in year first than second year. Mean value of $\mathrm{W}_{\mathrm{w}}$ was found higher in year second than year first (Table 2).

\section{Shift in tree phenology}

Species differed for their phenophases timing in studied years. Timing of leaf emergence, leaf damage and leaf senescence shifted in studied years (Table 3). Species differed for their leaf emergence timing in studied years. In $Q$. semecarpifolia leaf emergence delayed by two months, leaf damage delayed by two weeks, and leaf senescence delayed by two months. Similarly, $Q$. lamellosa leaf emergence delayed by two weeks, leaf damage delayed by two weeks and leaf senescence delayed by one month. In $Q$. glauca emergence advanced by three weeks, leaf damage delayed by nine weeks and leaf senescence advanced by one month.
Table 1. Mean values $( \pm \mathrm{SE})$ of measurement for each species during all sampling dates, mean wood water content in percent $\left(W_{c}\right)$ wood density $\left(W_{D}\right)$ and water in $\operatorname{wood}(\mathbf{W w})$. Units for $\left.W_{D}\right)$ and (Ww) are $\mathrm{g} \mathrm{cm}^{3}$. Within columns, different letters indicate significant difference ( $P=0.05$, Fishers' multiple range test).

\begin{tabular}{lccc}
\hline \multicolumn{1}{c}{ Species } & $\mathbf{W}_{\mathbf{c}}$ & $\mathbf{W}_{\mathbf{D}}$ & $\mathbf{W}_{\mathbf{w}}$ \\
\hline Q. galuca & $64.43 \pm$ & $0.67 \pm 0.04 \mathrm{a} 0.69 \pm 0.05 \mathrm{a}$ \\
& $4.29 \mathrm{a}$ & & \\
Q. semecarpifolia & $79.45 \pm$ & $0.97 \pm$ & $0.96 \pm$ \\
& $9.13 \mathrm{a}$ & $0.07 \mathrm{~b}$ & $0.07 \mathrm{~b}$ \\
Q. lamellosa & $71.16 \pm$ & $0.92 \pm$ & $0.98 \pm$ \\
& $7.99 \mathrm{a}$ & $0.05 \mathrm{~b}$ & $0.08 \mathrm{~b}$ \\
\hline
\end{tabular}

Table 2. Mean values of measurement for each species during two sampling years, wood water content in percent $\left(W_{c}\right)$ wood density $\left(W_{D}\right)$ and water in wood $\left(\mathrm{Ww}_{\mathrm{w}}\right)$. Units for $\left.\mathrm{W}_{\mathrm{D}}\right)$ and $\left(\mathrm{Ww}_{\mathrm{w}}\right)$ are $\mathrm{g} \mathrm{cm}^{-3}$. Year $1=$ October 2015 to June 2016, Year 2+ October 2016 to June 2017.

\begin{tabular}{lcccc}
\hline $\begin{array}{l}\text { Variable } \\
\mathbf{s}\end{array}$ & Year & $\begin{array}{c}\boldsymbol{Q} . \\
\text { semecarpifolia }\end{array}$ & Q. galuca & Q. lamellosa \\
\hline $\mathrm{W}_{\mathrm{c}}$ & 1 & $90.40 \pm 18.25$ & $67.14 \pm$ & $75.66 \pm$ \\
& & & 8.36 & 16.83 \\
& 2 & $71.29 \pm 5.93$ & $59.20 \pm$ & $66.39 \pm 4.77$ \\
& & & 3.57 & \\
$\mathrm{~W}_{\mathrm{D}}$ & 1 & $1.24 \pm 0.04$ & $0.84 \pm 0.03$ & $1.12 \pm 0.05$ \\
& 2 & $0.72 \pm 0.03$ & $0.54 \pm 0.02$ & $0.75 \pm 0.01$ \\
$\mathrm{~W}_{\mathrm{w}}$ & 1 & $0.67 \pm 0.03$ & $0.51 \pm 0.02$ & $0.68 \pm 0.05$ \\
& 2 & $1.23 \pm 0.01$ & $0.85 \pm 0.03$ & $1.25 \pm 0.02$ \\
\hline
\end{tabular}

Fig. 1. Monthly variations in rainfall and temperature pattern during study period. Bar represent rainfall, lines with solid triangles minimum temperature and solid squares maximum temperature.

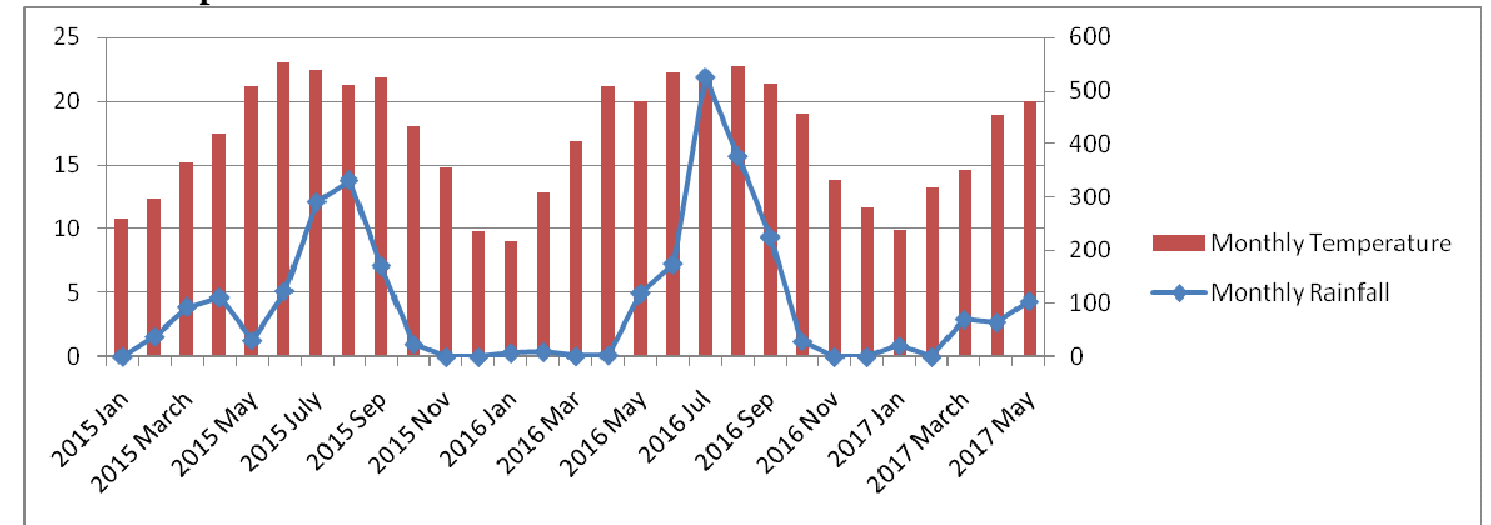

Source: Department of Hydrology and Meteorology, Kathmandu, Nepal. The data were recorded at Godavari Station $\left(27^{\circ} 6^{\prime} \mathrm{N}, 85^{\circ} 4^{\prime} \mathrm{E}\right.$, alt. $\left.1527 \mathrm{masl}\right)$, which is about $1 \mathrm{~km}$ east of the study site. 
Table 3. Shift in the timing of tree phenophases (advanced/delayed)

\begin{tabular}{|c|c|c|c|c|c|}
\hline SN & Species & Phenophases & Year 1 & Year 2 & Remarks \\
\hline \multirow[t]{3}{*}{1} & $\begin{array}{l}\text { Quercus } \\
\text { semecarpifolia }\end{array}$ & $\begin{array}{l}\text { Leaf Emergence } \\
\text { Commencement }\end{array}$ & April Second Week & $\begin{array}{l}\text { June Second } \\
\text { Week }\end{array}$ & $\begin{array}{l}\text { Delayed by } 2 \\
\text { months }\end{array}$ \\
\hline & & Leaf Damage & $\begin{array}{l}\text { January Second } \\
\text { Week }\end{array}$ & $\begin{array}{l}\text { January Fourth } \\
\text { Week }\end{array}$ & $\begin{array}{l}\text { Delayed by } 2 \\
\text { Weeks }\end{array}$ \\
\hline & & Leaf Senescence & March Third Week & May Third Week & $\begin{array}{l}\text { Delayed by } 2 \\
\text { months }\end{array}$ \\
\hline \multirow[t]{3}{*}{2} & Quercus lamellosa & $\begin{array}{l}\text { Leaf Emergence } \\
\text { Commencement }\end{array}$ & April First Week & $\begin{array}{l}\text { March Third } \\
\text { Week }\end{array}$ & $\begin{array}{l}\text { Advanced by } 2 \\
\text { weeks }\end{array}$ \\
\hline & & Leaf Damage & $\begin{array}{l}\text { November Second } \\
\text { Week }\end{array}$ & $\begin{array}{l}\text { January Second } \\
\text { Week }\end{array}$ & $\begin{array}{l}\text { Delayed by } 2 \\
\text { months }\end{array}$ \\
\hline & & Leaf Senescence & April Second Week & $\begin{array}{l}\text { March Second } \\
\text { Week }\end{array}$ & $\begin{array}{l}\text { Advanced by } 1 \\
\text { month }\end{array}$ \\
\hline \multirow[t]{3}{*}{3} & Quercus glauca & $\begin{array}{l}\text { Leaf Emergence } \\
\text { Commencement }\end{array}$ & May Second Week & April Third Week & $\begin{array}{l}\text { Advanced by } 3 \\
\text { weeks }\end{array}$ \\
\hline & & Leaf Damage & $\begin{array}{l}\text { January Second } \\
\text { Week }\end{array}$ & $\begin{array}{l}\text { March Third } \\
\text { Week }\end{array}$ & $\begin{array}{l}\text { Delayed by } 9 \\
\text { weeks }\end{array}$ \\
\hline & & Leaf Senescence & May Second Week & $\begin{array}{l}\text { April Second } \\
\text { Week }\end{array}$ & $\begin{array}{l}\text { Advanced by } 1 \\
\text { month }\end{array}$ \\
\hline
\end{tabular}

\section{DISCUSSION}

The analysis of the rainfall data of the Godavari station (close to study site) for the study period (October 2015 to June 2017) shows interannual and seasonal variation in rainfall in the study period. Data show that total annual rainfall and number of rain days found higher in year second than year first. Analysis of monthly rainfall data revealed that the annual rainfall increased from $1084.2 \mathrm{~mm}$ during the Year 1 to $1593.7 \mathrm{~mm}$ during the Year 2, number of rain days increased from 113 days during the Year 1 to 133 days during the Year 2. Similarly, analysis of seasonal rainfall data revealed that the monsoon rainfall increased from $918.5 \mathrm{~mm}$ during the Year 1 to $1303.3 \mathrm{~mm}$ during the Year 2, post monsoon rainfall increased from $23.7 \mathrm{~mm}$ during the Year 1 to $29 \mathrm{~mm}$ during the Year 2, winter rainfall increased from $17.6 \mathrm{~mm}$ during the Year 1 to 21.0 $\mathrm{mm}$ during the Year 2, and pre-monsoon rainfall increased from 124.4 during the Year 1 to 240.4 $\mathrm{mm}$ during the Year 2. Month to month rainfall analysis during the January to May month revealed that rainfall amount increased in January, March and April slightly declined in February and May in Year 2 than Year 1. During the month of January, rainfall increased $7.8 \mathrm{~mm}$ in Year 1 to $21 \mathrm{~mm}$ in Year 2. During the month of March rainfall increased $1.6 \mathrm{~mm}$ in Year 1 to 70.7 in Year 2. Likewise, during the month of April rainfall increased $3.4 \mathrm{~mm}$ in Year 1 to $65 \mathrm{~mm}$ in Year 2. Similarly, during the month of February rainfall was $9.8 \mathrm{~mm}$ in Year 1 to no rainfall recorded in same month in Year 2. Similarly, during the month of May rainfall decreased slightly $119.4 \mathrm{~mm}$ in Year 1 to $104.7 \mathrm{~mm}$ in Year 2.

$\mathrm{W}_{\mathrm{c}}$ in studied species decreased in dry summer months in both years when leaf emergence took place thus implying utilization of stored stem water for bud break as suggested by Borchert (1994c), Poudyal et al. (2012). Means value of $\mathrm{W}_{\mathrm{c}}$ found higher in year first than second year. Inter-annual and seasonal variation of rainfall might cause higher drought stress for trees in first year than year second thus higher stem water stored during dry summer months of year than year second and 
utilized stored stem water for leaf emergence April 2016. However, higher annual and seasonal rainfall in year 2 might cause lower drought stress than year 1 resulting lower stem water storage in year 2 during dry summer and utilized stored stem water for leaf emergence in June 2016 only as lower drought stress for trees compared to year 1. A pronounced relationship between $\mathrm{W}_{\mathrm{c}}$ and leaf emergence was found in all species. Species differed for their leaf emergence timing in studied years due to inter annual and monthly variation in wood water content.

$\mathrm{W}_{\mathrm{w}}$ in studied species increased in dry summer months in both years when leaf emergence took place. Mean value of $\mathrm{W}_{\mathrm{w}}$ in studied species found higher in year 2 than year 1 as rainfalls during premonsoon, monsoon, post monsoon and winter seasons comparatively found higher in Year 2 than Year 1.

$\mathrm{W}_{\mathrm{D}}$ in studied species found increased in dry summer months in both years when leaf damage and leaf senescence took place as senescence is a functional strategy of the plants to maintain a favorable tissue water status as the decreased leaf surface area eliminates higher fraction of water loss through transpiration as reported by Poudyal (2004). Mean values of $\mathrm{W}_{\mathrm{D}}$ found higher in year 1 than year 2. Higher wood density of trees in year 1 might afford high tolerance to drought stress having high physical strength with thick cell wall during the dry season as suggested by Holbrook et al. (1995) and Onoda et al. (2010). Species differed for their leaf damage and leaf senescence timing in studied years due to inter annual and monthly variation in wood density. A prominent relationship between leaf damage and leaf senescence with $\mathrm{W}_{\mathrm{D}}$ was found in all species. Leaf damage and leaf senescence commenced in studied species in dry summer months with the increase in $\mathrm{W}_{\mathrm{D}}$. In year first, $Q$. semecarpifolia leaf damage started in January second week and leaf senescence started in March and $\mathrm{W}_{\mathrm{D}}$ increased from December to February. In year second, $Q$. semecarpifolia leaf damage started in January fourth week and leaf senescence started in May and $\mathrm{W}_{\mathrm{D}}$ increased from February to April. Similarly, in year first $Q$. lamellosa leaf damage started in November and leaf senescence started in April and $\mathrm{W}_{\mathrm{D}}$ increased from November to February. In year second $Q$. semecarpifolia leaf damage started in January fourth week and leaf senescence started in March and $\mathrm{W}_{\mathrm{D}}$ increased from March to May. Likewise, in year first $Q$. glauca leaf damage started in January and leaf senescence started in May and $\mathrm{W}_{\mathrm{D}}$ increased from December to January. In year second $Q$. glauca leaf damage started in March and leaf senescence commenced in April and $\mathrm{W}_{\mathrm{D}}$ increased from February to May. Inter-annual variations of rainfall may cause strong drought stress for trees because exceptional leaf shedding occurs in evergreen canopy trees during the dry season in years of extremely low rainfall (Iida $e t$ al. 2013). Trees with high wood density may afford high tolerance to drought stress (Holbrook et al. 1995). The major phenological events occurred during the dry summer months and were highly affected by wood water content, wood density and water in wood due to profound effect of winter and pre-monsoon rainfall.

\section{CONCLUSION}

Erratic rainfall pattern is thought to dramatically affect phenological shifts. The results of this study indicate that wood water properties have an important role in timing of leaf emergence, leaf damage and leaf senescence. Our results indicate that the inter-annual and monthly variation in wood water content, wood density and water in wood due to seasonal and annual variation in rainfall influence the timing of phenophases in three Himalayan oak species resulting individual shift in their leaf phenology. 


\section{ACKNOWLEDGEMENT}

We would like to express our gratitude to Dr. Anjana Bista, Ramesh Chhetri and Saroj Adhikari for their help during the field study. We would also like to acknowledge NAST-CCRGP Project (Nepal Academy of Science and Technology and Asian Bank Development, TA 7984 NEP) for funding.

\section{REFERENCES}

Aitken, S.N., S. Yeaman, J.A. Holliday, T. Wang and S. Curtis-McLane. 2008. Evolutionary applications. Adaptation, migration or extirpation: climate change outcomes for tree populations. Synthesis 1:95-111.

Anderson, D.P., E.V. Nordheim, T.C. Moermond, Z.B. Gone Bi and C. Boesch. 2005. Factors influencing tree phenology in Tai National Park, Cote d'Ivoire. Biotropica 37:631-640.

Averty, M.T., H.L. Miller (Eds.). 2007. Climate Change 2007: The Physical Science Basis. Cambridge University Press, Cambridge, UK, 996 p.

Badeck, F.W., A. Bondeau, K. Böttcher, D. Doktor, W. Lucht, J. Schaber and S. Sitch. 2004. Responses of spring phenology to climate change. New Phytologist 162:295309.

Borchert, R., G. Rivera and W. Hagnauer. 2002. Modification of vegetative phenology in a tropical semideciduous forest by abnormal drought and rain. Biotropica 34:27-39.

Borchert, R. 1994c. Soil and stem water storage determine phenology and distribution of tropical dry forest trees. Ecology 75:14371449.

Chmielewski, F.M. and T. Rotzer. 2001. Response of tree phenology to climate change across Europe. Agricultural and Forest Meteorology 108:101-112.
Christensen, J.H., B. Hewitson, A. Busuioc, A. Chen, X. Gao, R. Held, R. Jones, R.K. Kolli, W.T. Kwon, V. Laprise, L. Magana Rueda, G.G. Mearns, C.G. Menendez, J. Rainsanen, A. Rinke, A. Sarr and P. Whetton. 2007. Regional climate projections. In: Climate Change 2007: The Physical Science Basis. Contribution of Working Group I to the Fourth Assessment Report of the Intergovernmental Panel on Climate Change. (eds.) Solomon, S., D. Qin, M. Manning, Z. Chen, M. Marquis, K.B. Averyt, M. Tignor and H.L. Miller. Cambridge University Press, Cambridge, UK and New York, NY, USA, 2007.

Curran, L.M. and M. Leighton. 2000. Vertebrate responses to spatiotemporal variation in seed production of mast-fruiting Dipterocarpaceae. Ecological Monographs 70:101-128.

Davi, H., E. Dufrene, C. Fransois, et al. 2006. Sensitivity of water and carbon fluxes to climate changes from 1960 to 2100 in European forest ecosystem. Agr. Forest. Meteorol. 141:35-56.

DHM. 2017. Observed Climate Trend Analysis in the Districts and Physiographic Regions of Nepal (1971-2014). Department of Hydrology and Meteorology, Kathmandu.

Holbrook, N.M. et al. 1995. Drought responses of neotropical dry forest trees. In: Seasonally Dry Tropical Forests. (eds.) Bullock, S.H. et al. Cambridge University Press, UK, Cambridge, pp. 243-276.

IPCC. 2007. Contribution of working group I to the fourth assessment report of the intergovernmental panel on climate change. In: Solomon, S.D., M.M. Qin., Z.M. Chen, K.B. Marquis.

IPCC. 2007. The Fourth Assessment Report: Climate Change 2007; Synthesis Report; Cambridge University Press: Cambridge, UK, 2007. 
IPCC. 2007. Summary for policymakers. In: Intergovernmental Panel on Climate Change Special Report on managing the Risks of Extreme Events and Disasters to Advance Climate Change Adaptation. (eds.) Field, C.B., V. Barros, T.f. Stocker, D. Qin, D. Dokken, K.L. Ebi, M.D. Mastrandrea and K.J. Mach.

Lida, S. et al. 2013. Year-to-year differences in sap flow and crown-level stomatal conductance of two species in a lowland evergreen forest, central Cambodia. JARQ 47:319-327.

Matsumoto, K., T. Ohta, M. Irasawa and T. Nakamura. 2003. Climate change and extension of the Ginkgo biloba L. growing season in Japan. Global Change Biology 9:1634-1642.

Menzel, A., T.H. Sparks, N. Estrella, et al. 2006. European phenological response to climate change matches the warming pattern. Global Change Biology 12:1969-1976.

Moriondo, M. and M. Bindi. 2007. Impact of climate change on the phenology of typical mediterranean crops. Italian Journal of Agrometeorology 30:5-12.

Nord, E.A. and J.P. Lynch. 2009. Plant phenology: A critical controller of soil resource acquisition. Journal of Experimental Botany 60:1927-1937.

Onoda, Y. et al. 2010. The relationship between stem biomechanics and wood density is modified by rainfall in 32 Australian woody plant species. New Phytol. 185:493-501.

Plattner, G.K., S.K. Allen, M. Tignor and P.D. Midgley. 2011. Cambridge University Press, Cambridge, UK and New York, NY, USA.

Poudyal, K., P.K. Jha, D.B. Zobel and C.B. Thapa. 2004. Patterns of leaf conductance and water potential of five Himalayan tree species. Tree Physiology 24:689-699.
Poudyal, K., P.K. Jha, D.B. Zobel and C.B. Thapa. 2012. Role of wood water properties and leaf dynamics in phenology and response to drought in evergreen Himalayan tree specices. Ecoprint 19:71-84.

Ragusa-Netto, J. and R.R. Silva. 2007. Canopy phenology of a dry forest in western Brazil. Brazilian Journal of Biology 67:569-575.

Sakai, S., R.D. Harrison, K. Momose, K. Kuraji, H. Nagamasu, T. Yasunari, L. Chong and T. Nakashizuka. 2006. Irregular droughts trigger mass flowering in aseasonal tropical forests in Asia. American Journal of Botany 93:11341139.

Singh, K.P. and C.P. Kushwaha. 2005. Emerging paradigms of tree phenology in dry tropics. Current Science 89:964-975.

Singh, K.P. and C.P. Kushwaha. 2006. Diversity of flowering and fruiting phenology of trees in a tropical deciduous forest in India. Annals of Botany 97:265-276.

Smith, M.D. 2011. An ecological perspective on extreme climatic events: A synthetic definition and framework to guide future research. $J$. Ecol., 99:656-663.

Sparks, T.H. and A. Menzel. 2002. Observed changes in seasons: An overview. International Journal of Climatology 22:1715-1725.

Thakur, P.S., V. Dutt and A. Thakur. 2008. Impact of inter-annual climate variability on the phenology of eleven multipurpose tree species. Current Science 94:1053-1058.

Walther, G.R., E. Post, P. Convey, A. Menzel, C. Parmesan, T.J.C. Beebee, J.M. Fromentin, O. Hoegh-Guldberg and F. Bairlein. 2002. Ecological responses to recent climate change. Nature 416:389-395.

Yadav, R.K. and A.S. Yadav. 2008. Phenology of selected woody species in a tropical dry deciduous forest in Rajasthan, India. Tropical Ecology 49:25-34. 